\title{
Composite Wood-Concrete Structural Floor System with Horizontal Connectors
}

\author{
Ruy A. SáRibeiro*, and Marilene G. SáRibeiro
}

(Received December 20, 2013, Accepted September 18, 2014, Published online October 1, 2014)

\begin{abstract}
The concept of horizontal shear connection utilization on wood-concrete beams intends to be an alternative connection detail for composite wood-concrete decks. The volume of sawn-wood is over three times more expensive than concrete, in Brazil. In order to be competitive in the Brazilian market we need a composite deck with the least amount of wood and a simple and inexpensive connection detail. This research project uses medium to high density tropical hardwoods managed from the Brazilian Amazon region and construction steel rods. The beams studied are composed of a bottom layer of staggered wood boards and a top layer of concrete. The wood members are laterally nailed together to form a wide beam, and horizontal rebar connectors are installed before the concrete layer is applied on top. Two sets of wood-concrete layered beams with horizontal rebar connectors (6 and 8) were tested in third-point loading flexural bending. The initial results reveal medium composite efficiency for the beams tested. An improvement on the previously conceived connection detail (set with six connectors) for the composite wood-concrete structural floor system was achieved by the set with eight connectors. The new layout of the horizontal rebar connectors added higher composite efficiency for the beams tested. Further analysis with advanced rigorous numerical Finite Element Modeling is suggested to optimize the connection parameters. Composite wood-concrete decks can attend a large demand for pedestrian bridges, as well as residential and commercial slabs in the Brazilian Amazon.
\end{abstract}

Keywords: composite, wood-concrete, shear connector, composite efficiency, rebar connector, layered beams, tropical hardwood, Amazonia.

\section{Introduction}

In spite of the existence of more than 2,500 different wood species catalogued in the Brazilian Amazon (SáRibeiro and SáRibeiro 1990), wood is very little used in Brazil as an engineered structural element (excluding conventional structures for residential roofs). Engineered wood structures are largely used in the developed countries for constructions of schools, churches, commercial and industrial buildings, residences, pavilions, highway and railway bridges, towers, theater screens, ships, military and marine installations.

The conventional construction of a reinforced concrete slab presents a high degree of wasted materials, and the steel reinforcement is expensive. The tension zone cracks and half of its thickness is ineffective, only holding the steel reinforcement in place (Gutkowski et al. 2000). The tension cracks can allow access to moisture, causing corrosion, separation, and other types of degeneration. Exposed rebar is also a potential problem for fire protection.

Structural Engineering Laboratory, National Institute for Amazonian Research (INPA), Manaus, AM 69060-001, Brazil.

*Corresponding Author; E-mail: ruy.saribeiro3@gmail.com Copyright $($ The Author(s) 2014. This article is published with open access at Springerlink.com
This research aims to substitute part of the concrete and the expensive rebar by a solid Amazonian wood deck structurally effective. Since the wood deck can substitute the normal formwork, the gain is leaving it in place, reducing in half the thickness of the slab and interconnecting them. This also results in economy of the construction cost. The competitive merit of this mixed construction is supported by several examples of successful pilot projects in Europe and in the USA (Gutkowski et al. 2000, 1999a, b, 2001, 2002, 2004, 2008; Gutkowski and Chen 1996; Brown 1998; Brown et al. 1998; Chen et al. 1992; Etournaud 1998; Etournaud et al. 1998; Fragiacomo et al. 2007; Fragiacomo and Ceccotti 2006; Fragiacomo 2006; Ceccotti et al. 2006; Faggiano et al. 2009), and more recently in Brazil (SáRibeiro et al. 2006). In the recent decade the mixed construction has advanced to many constructions in Europe of multi-story apartment buildings, office buildings and some bridge decks (Grantham et al. 2004; Clouston and Schreyer 2008). Nowadays actual buildings are going up and Euro code provisions exist in detail for their design (Clouston and Schreyer 2008; Comité Européen de Normalisation 2002, 2003, 2004; Lukaszewska et al. 2008; Dias et al. 2011; Fragiacomo and Batchelar 2012; Fragiacomo and Schänzlin 2013).

The objective of this work is to study the effectiveness of this connection detail, which is easy to fabricate (uses unskilled labor and handy tools) and has a low cost (uses 
conventional available low cost materials). The horizontal shear connection concept intends to be another alternative to be used for composite wood-concrete decks. This experiment used mid to high density tropical hardwoods managed from the Brazilian Amazon region and 10-mm diameter construction steel rods.

\section{Connection Detail}

In order to achieve a high degree of composite action the interlayer connections must reduce slip to low magnitude. The flexure of layered elements results in a tendency for relative longitudinal motion at their interface.

The shear connection detail achieves interlayer shear transfer by bearing stresses and horizontal shear in the drilled wood holes (Fig. 1). Since interlayer slip is low, the anchor connector itself is not subjected to shear. It only resists uplift created by the bearing force in the wood holes. The connection for this experiment used steel rod couples embedded into pre-drilled holes across the laminated wood beam. Further details are presented in Sect. 3.

\section{Experimental Procedures}

\subsection{Beam Specimens}

Two sets of three wood-concrete layered beams, each, were tested. Each beam represented a portion of the width of a layered wood concrete longitudinal deck specimen.

For set-1 (with six connectors), all staggered wood deck for beams V1 and V2 was Mandioqueira (Qualea
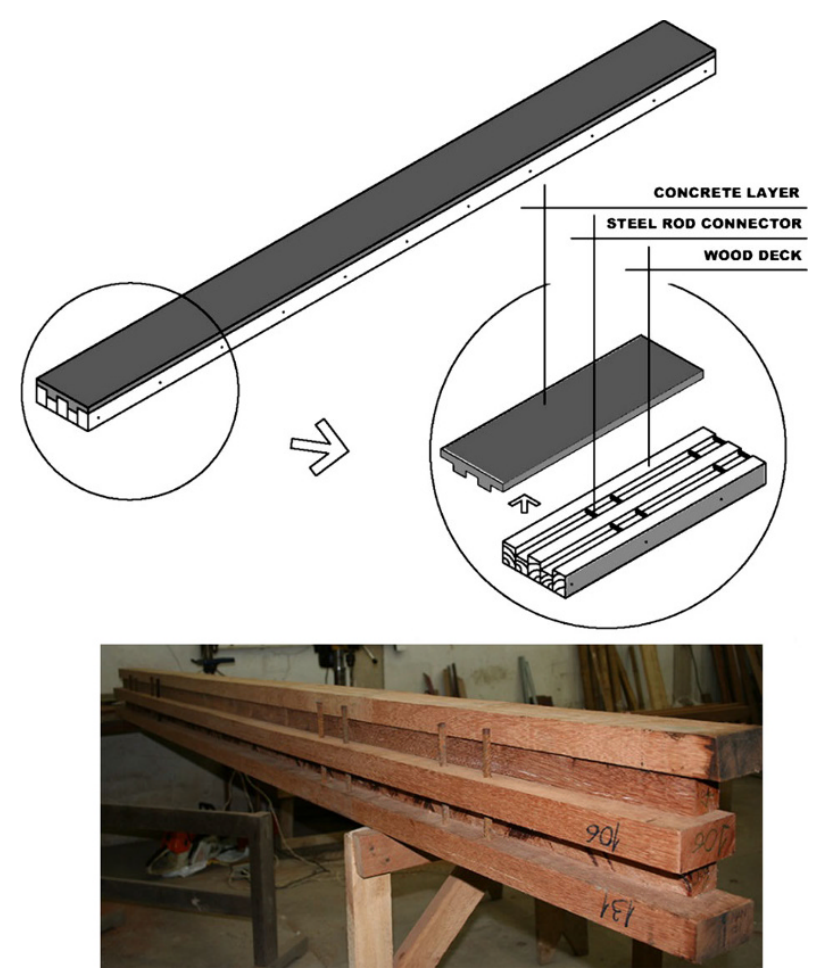

Fig. 1 Wood-concrete beam and horizontal shear connection detail. acuminata), and for V3 was Angelim-pedra (Hymenolobium petraceum) in the outer layers and Mandioqueira in the middle layer. The wood was surfaced dry, $50 \times 75 \mathrm{~mm}$ and $50 \times 38 \mathrm{~mm}$ nominal size dimension lumber tested at an average $15 \%$ moisture content (MC) condition. The average specific gravity of the wood, at $15 \% \mathrm{MC}$, was 0.74 . The layered wood beam section used was a 3.05-m beam, composed of five vertical pieces of two alternating depths. Wood members were laterally nailed together with $80-\mathrm{mm}$ long galvanized spiral-shank nails in the vertical pattern shown in Fig. 2 as nails 1 through 4 . This pattern was repeated every $300 \mathrm{~mm}$ along the beam and at mid-span. In order to accommodate the horizontal shear connectors (10$\mathrm{mm}$ diameter construction steel rods), two 12-mm diameter holes, spaced $100 \mathrm{~mm}$ on-center, were pre-drilled at the midlength and at $300 \mathrm{~mm}$ from both ends of the $250-\mathrm{mm}$ wide beams. The holes penetrated the full thickness of the centerlayer wood member, and just half the thickness of the outerlayer wood members. The steel rod connectors were set in place before nailing the last outer-layer wood member, as shown in Fig. 1. Concrete formwork was constructed around the beams using 12-mm thick plywood, to accommodate a 30-mm deep top concrete lamina (Fig. 3).

For set-2 (with eight connectors), all staggered wood deck for beams MAN1, MAN2 and MAN4 was Mandioqueira $(Q$. acumminata) on the outer layers and in the middle layer. The wood was surfaced dry, $50 \times 100 \mathrm{~mm}$ and $50 \times 50 \mathrm{~mm}$ nominal size dimension lumber tested at an average $12 \%$ $\mathrm{MC}$ condition. The layered wood beam section used was a $3.05-\mathrm{m}$ beam, composed of five staggered vertical pieces (Fig. 1). Wood members were laterally nailed together, the same way as it was done for set 1 (Fig. 2; Tables 1 and 2). In order to accommodate the horizontal shear connectors (10$\mathrm{mm}$ diameter construction steel rods), two 12-mm diameter holes, spaced $100 \mathrm{~mm}$ on-center, were pre-drilled at $300 \mathrm{~mm}$ and at $700 \mathrm{~mm}$ from both ends of the $250-\mathrm{mm}$ wide beams. Each connector was set in place before nailing the last outer-layer wood member (Fig. 2). Concrete formwork was constructed around the beams using 12-mm thick plywood, as shown in Fig. 3.

The mechanical properties of the construction steel rods used are: modulus of elasticity, $E=200,100 \mathrm{MPa}$, and yield strength, $f_{y}=250 \mathrm{MPa}$. All wood members were nondestructively tested using the Metriguard Stress Wave Timer device to determine the longitudinal modulus of elasticity, $E_{d}$. The average values of $E_{d}$ for sets 1 and 2 were found to be 11,887 and $15,491 \mathrm{MPa}$, respectively.

The concrete layers for sets 1 and 2 were batch delivered with 18 and $10 \mathrm{MPa}$ specified strength (average values of three cylinders tested at the 28th day), respectively, consolidated by vibration and moist cured. After curing of the concrete the wood-concrete beams were transported to the laboratory for testing.

\subsection{Beam Tests}

Testing was done using an Instron Universal Testing Machine with a $500-\mathrm{kN}$ load cell capacity (set 1) and an Instron Actuator attached to a Test Frame with a $250-\mathrm{kN}$ 

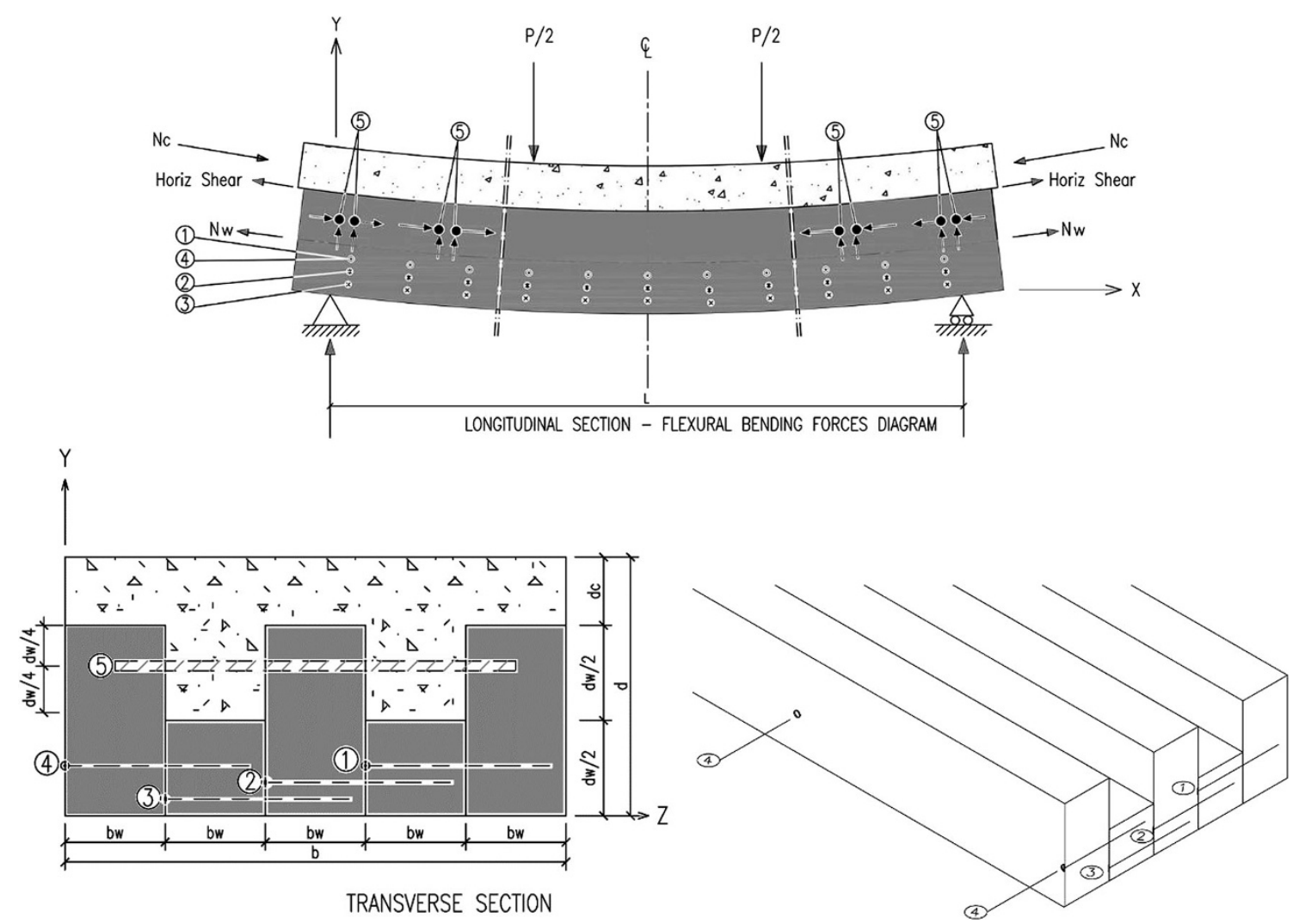

Fig. 2 Pattern of connectors for sets 1 and 2.

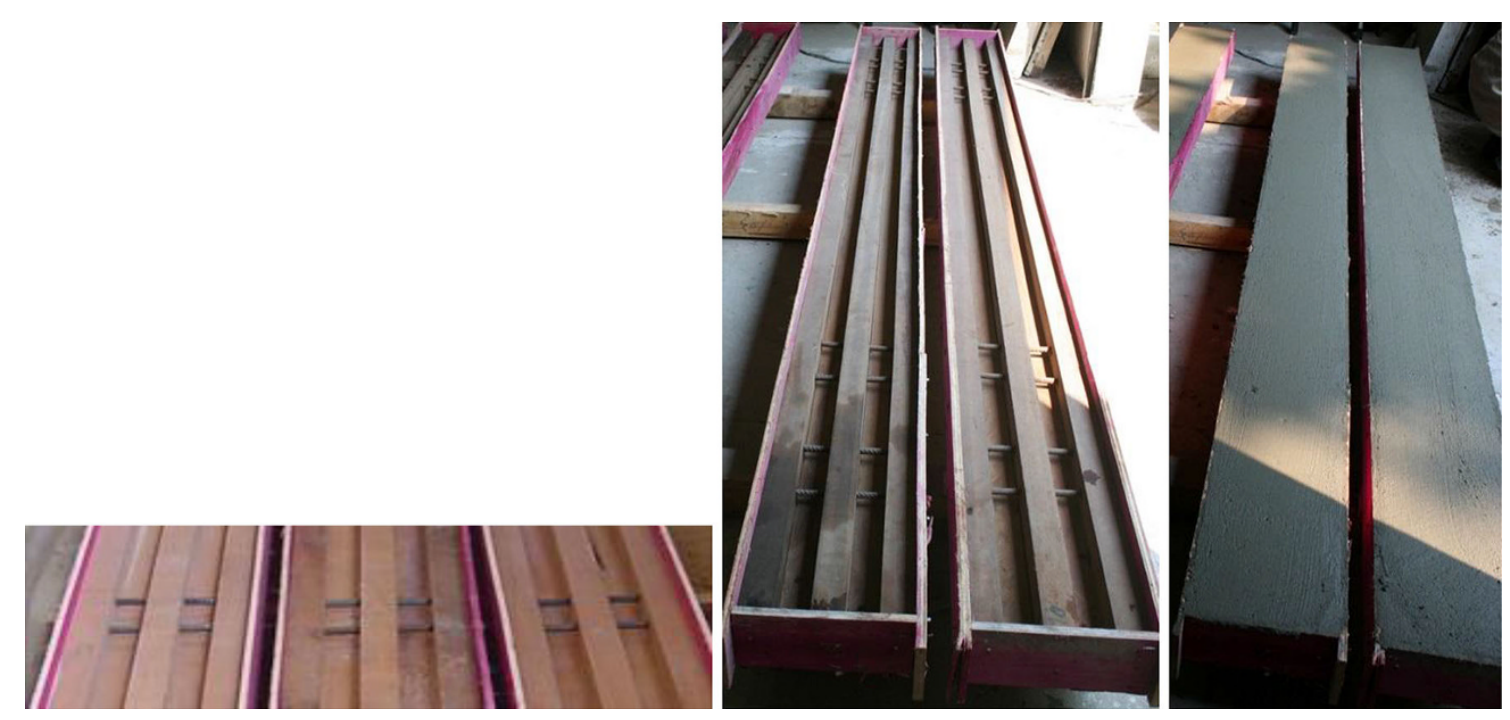

Fig. 3 Wood deck, steel connector, formwork, and finished beams.

Table 1 Beams sectional dimensions.

\begin{tabular}{c|c|c|c|c|c|c}
\hline SET & $b_{w}(\mathrm{~mm})$ & $d_{w}(\mathrm{~mm})$ & $d_{c}(\mathrm{~mm})$ & $b(\mathrm{~mm})$ & $d(\mathrm{~mm})$ & $L(\mathrm{~m})$ \\
\hline \hline 1 & 50 & 75 & 30 & 250 & 105 & 3.000 \\
\hline 2 & 50 & 100 & 30 & 250 & 130 & 3.000 \\
\hline
\end{tabular}

calibrated load cell capacity (set 2) at a speed of $10 \mathrm{~mm} / \mathrm{min}$ up to rupture. Beam specimens were loaded with a third point loading and simply supported over a 3.0-m clear span.
Deflections were measured at mid-span using potentiometers (Figs. 4 and 5). Also, measurements of slip between the wood and concrete layers were taken at both ends of each 
Table 2 Nailing steps (10-mm apart) and paired connector details (100-mm apart).

\begin{tabular}{c|c|c|c|c|c}
\hline \multirow{2}{*}{ SET } & \multicolumn{2}{|c|}{ Nail (1)(3) } & \multicolumn{3}{c}{ Paired connector (5) } \\
\cline { 2 - 6 } & Spacing (mm) & Edge dist. (mm) & Spacing o-c (mm) & Edge dist. (mm) & Length (mm) \\
\hline \hline 1 & 300 & 25 & 1,425 & 25 & 175 \\
\hline 2 & $250-300$ & 50 & 400 & 300 & 175 \\
\hline
\end{tabular}

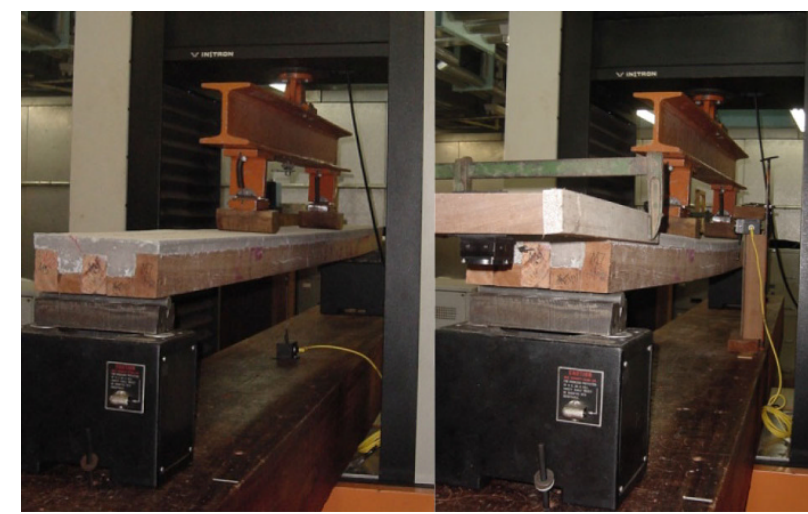

beam (Figs. 4 and 5). The potentiometers were Celesco position transducers with a measuring range of $254 \mathrm{~mm}$ and a position sensitivity of $94 \mathrm{mV} / \mathrm{V} / \mathrm{inch}$. The testing procedure was the following:

(1) Connect the potentiometers to the beam.

(2) Apply third point loading at a load rate of $10 \mathrm{~mm} / \mathrm{min}$ up to rupture, using an Instron Universal Testing Machine (set 1) and an Instron Actuator attached to a Test Frame (set 2). Measure and record displacements and load. Load and displacements are measured from LabView VI.

Fig. 4 Wood-concrete beam test specimens for set 1 .

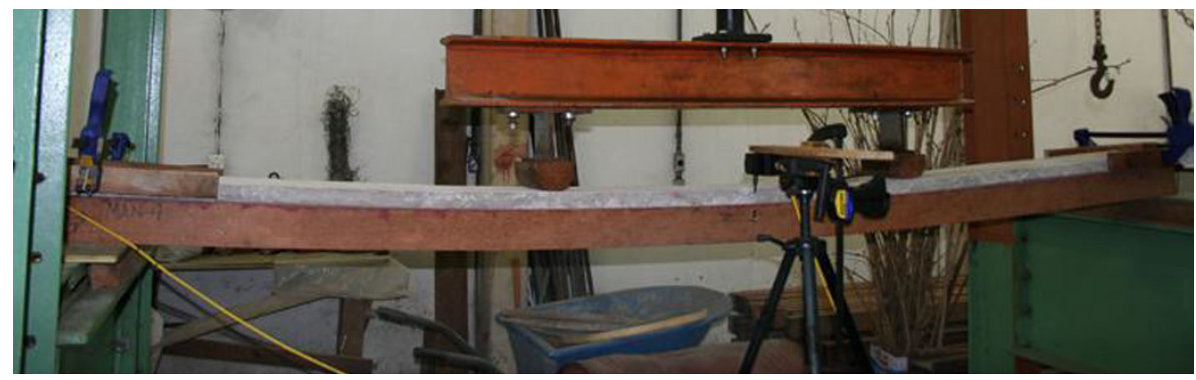

Fig. 5 Wood-concrete beam tested on third-point loading for set 2.
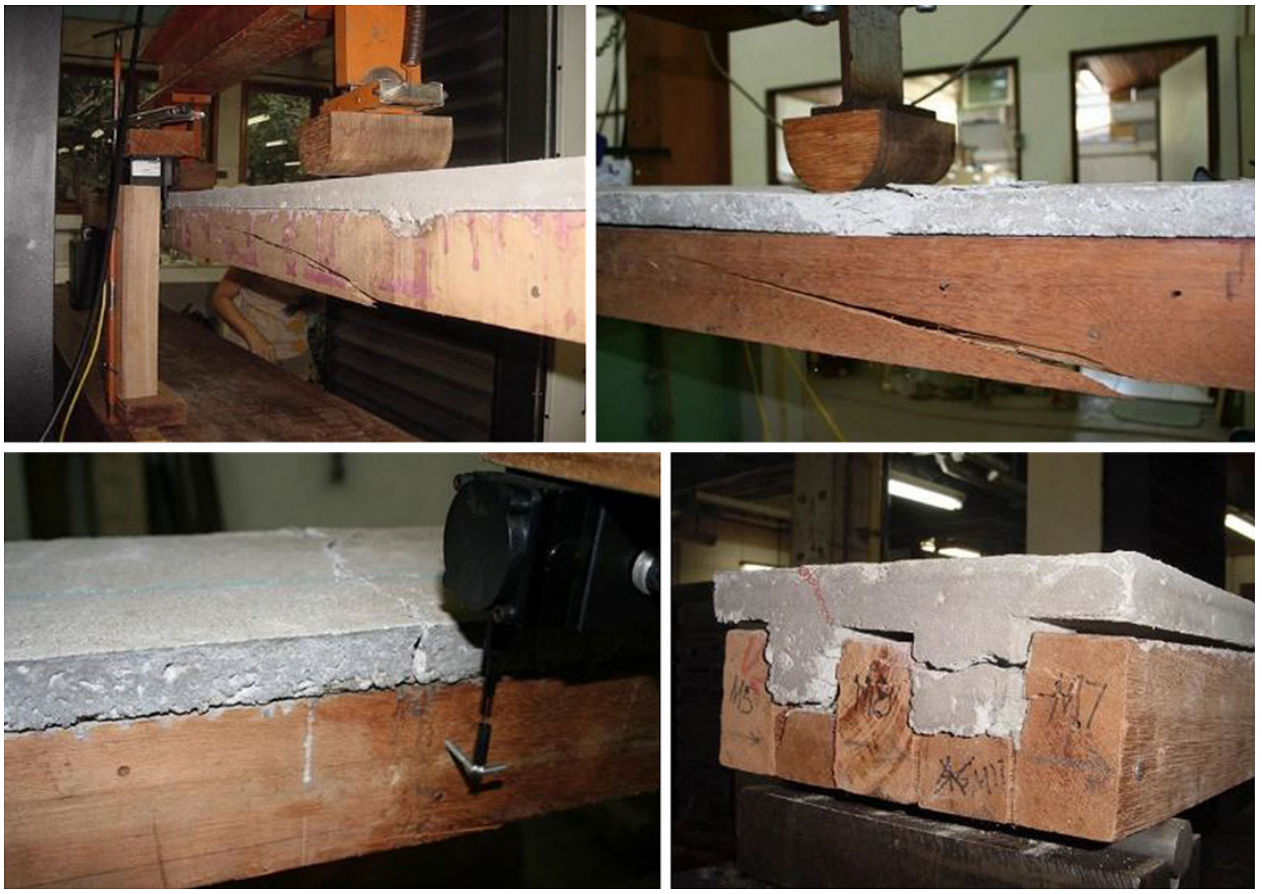

Fig. 6 Tensile failure in the wood and shearing of the concrete. 

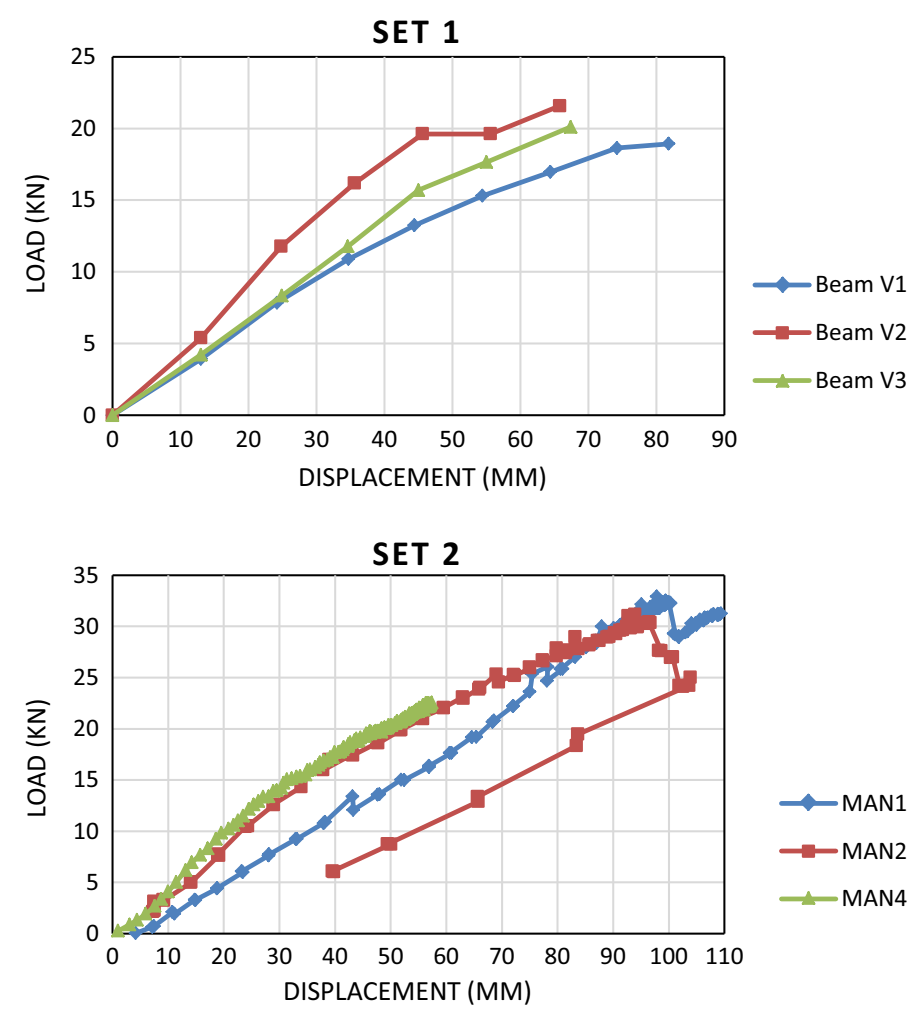

Fig. 7 Load-displacement at the center of the beams for sets 1 and 2 .

Table 3 Composite efficiency of the composite beams from set 2.

\begin{tabular}{c|c|c|c|c|c}
\hline BEAM & $P_{u}(\mathrm{~N})$ & $D_{\max }(\mathrm{mm})$ & $D_{f c}(\mathrm{~mm})$ & $D_{n c}(\mathrm{~mm})$ & CEF $(\%)$ \\
\hline \hline MAN1 & 32,929 & 97.85 & 17.7 & 160.4 & 43.84 \\
\hline MAN2 & 31,151 & 93.93 & 16.8 & 151.7 & 42.83 \\
\hline MAN4 & 22,567 & 57.39 & 12.2 & 109.9 & 53.73 \\
\hline AVG & 28,882 & 83.1 & 15.6 & 27.0 & 46.80 \\
\hline SD & 5,541 & 22.3 & 3.0 & 19.19 & 6.02 \\
\hline COV (\%) & 19.19 & 26.86 & 19.19 & 12.87 \\
\hline
\end{tabular}

\section{Analysis and Results}

The experiment for set 1 used 6 connectors per $0.75 \mathrm{~m}^{2}$ (top horizontal surface) for each beam, while for set 2 used eight connectors. All beams tested showed tensile failure in the wood and shearing of the concrete (Fig. 6). The tensile failure in the wood was mainly due to cross grain. A plot for the load-displacement of the beams tested on third-point loading flexural bending is depicted in Fig. 7. The registration of the same load value at the sixth point of set 1 may be due to an instant disturbance of the loading instrumentation. However, this single episode was considered not to be detrimental to the overall testing results.

Efficiency of the layered beams in developing composite action was determined using an established definition (Pault and Gutkowski 1977),

$$
\text { Efficiency }=\frac{D_{n c}-D_{m}}{D_{n c}-D_{f c}} \times 100
$$

where $D_{n c}$ is the theoretical non-composite deflection, $D_{f_{c}}$ is the theoretical fully composite deflection, and $D_{m}$ is the measured deflection for incomplete composite action of the specimen. $D_{n c}$ is computed as a layered beam without shear transfer,

$$
D_{n c}=\frac{23 P_{u} L^{3}}{648\left(E_{w} I_{w}+E_{c} I_{c}\right)}
$$

where $P_{u}$ is the ultimate load, $L$ is the span, $E_{w}$ and $I_{w}$ are, respectively, the wood modulus of elasticity and moment of inertia, $E_{c}$ and $I_{c}$ are, respectively, the concrete modulus of elasticity and moment of inertia. $D_{f c}$ is calculated by the transformed section, 


$$
D_{f c}=\frac{23 P_{u} L^{3}}{648 E_{w} I_{t r}}
$$

where $I_{t r}$ is the transformed section moment of inertia. The values for Eqs. (1) to (3) are given in Table 3.

The three beams tested with eight horizontal shear connectors (set 2) presented an average $47 \%$ degree of composite action efficiency. Previous tests with six horizontal shear connectors (set 1 ) resulted in $32 \%$ of composite action efficiency (SáRibeiro et al. 2006). The test of the three wood-concrete beams with eight horizontal shear connectors and medium to high density tropical hardwoods showed a composite system $47 \%$ more efficient than the pilot test with six horizontal shear connectors (SáRibeiro et al. 2006).

\section{Discussion and Conclusions}

It is possible to achieve a reasonable degree of composite action (for short term ramp loading) in layered wood concrete deck specimens using nominal dimension lumber and a horizontal shear anchor detail. An improvement on the previously conceived connection detail (set with six connectors) for the composite wood-concrete structural floor system was achieved by the set with eight connectors. The new layout of the horizontal rebar connectors added higher composite efficiency for the beams tested. The results reveal increased medium composite efficiency for the beams tested. Further analysis with advanced rigorous numerical Finite Element Modeling is suggested to optimize the connection parameters in terms of spacing and number of connectors. Composite wood-concrete decks can attend a large demand for pedestrian and road bridges in rural areas, as well as residential and commercial slabs. Durability under repetitive loads and extremes of temperature and humidity need to be examined, particularly for possible applications in bridge decks. This can be achieved using rigorous time-dependent and long term 3D models of sustained and repeated loading to demonstrate the performance over time of the connection detail (Fragiacomo and Ceccotti 2006; Fragiacomo 2006; Ceccotti et al. 2006).

Two important non-technical benefits of the mixed material construction are cost savings of replacing nonrenewable resource based concrete and steel with a managed renewable resource; and savings in energy of material production and construction. Changes from concrete and steel to more wood construction can substantially reduce energy requirements and carbon dioxide emissions (Natterer 1997; Wegener and Zimmer 1998; Winter 1998). These realities and the outcome of this study encourage considering the feasibility of wood concrete composites as a new application of dimension lumber in Brazil.

\section{Open Access}

This article is distributed under the terms of the Creative Commons Attribution License which permits any use, distribution, and reproduction in any medium, provided the original author(s) and the source are credited.

\section{References}

Brown, K. T. (1998). Testing of a Shear Key/Anchor in Layered Wood/Concrete Beams. M. S. Thesis, Department of Civil Engineering, Colorado State University, Ft. Collins, CO.

Brown, K. T., Gutkowski, R. M., Criswell, M. E., \& Peterson, M. L. (1998). Testing of a shear key/anchor in layered wood/concrete beams, Structural Research Report No. 76, Civil Engineering Department, Colorado State University, Ft. Collins, CO.

Ceccotti, A., Fragiacomo, M., \& Giordano, S. (2006). Longterm and collapse tests on a timber-concrete composite beam with glued-in connection. Materials and Structures, $40,15-25$.

Chen, T.-M., Gutkowski, R. M., \& Pellicane, P. J. (1992). Tests and analysis of mixed wood-concrete wood beams, Structural Research Report No. 69, Civil Engineering Department, Colorado State University, Ft. Collins, CO.

Clouston, P., \& Schreyer, A. (2008). Design and use of woodconcrete composites. Practice Periodical on Structural Design and Construction, 13(4), 167-174.

CEN, Comité Européen de Normalisation. (2002). EurocodeBasis of structural design. EN 1990. Brussels, Belgium.

CEN, Comité Européen de Normalisation. (2003). Eurocode 5-Design of timber structures. EN 1995-1. Brussels, Belgium.

CEN, Comité Européen de Normalisation. (2004). Eurocode 5-Design of timber structures. EN 1995-2. Brussels, Belgium.

Dias, A. M. P. G., Ferreira, M. C. P., Jorge, L. F. C., \& Martins, H. M. G. (2011). Timber-concrete practical applicationsbridge case study. Proceedings of the Institution of Civil Engineers: Structures and Buildings, 164(2), 131-141.

Etournaud, P. A. (1998). Loads Tests of Composite WoodConcrete Deckings Under Point Loads. M. S. Thesis, Department of Civil Engineering, Colorado State University, Ft. Collins, CO.

Etournaud, P. A., Gutkowski, R. M., Peterson, M. L., \& Criswell, M. E. (1998). Loads tests of composite wood-concrete deckings under point loads, Structural Research Report No. 81, Civil Engineering Department, Colorado State University, Ft. Collins, CO.

Faggiano, B., Marzo, A., Mazzolani, F. M., \& Calado, L. M. (2009). Analysis of rectangular-shaped collar connectors for Composite timber-steel-concrete floors: Push-out tests. Journal of Civil Engineering and Management, 15(1), 47-58.

Fragiacomo, M. (2006). Long-term behavior of timber-concrete composite beams. II: Numerical analysis and simplified evaluation. Journal of Structural Engineering, 132(1), 23-33.

Fragiacomo, M., \& Batchelar, M. (2012). Timber frame moment joints with glued-in steel rods. II: Experimental investigation of long-term performance. Journal of Structural Engineering, 138(6), 802-811.

Fragiacomo, M., \& Ceccotti, A. (2006). Long-term behavior of timber-concrete composite beams. I: Finite Element 
Modeling and validation. Journal of Structural Engineering, 132(1), 13-22.

Fragiacomo, M., Gutkowski, R. M., Balogh, J., \& Fast, R. S. (2007). Long-term behavior of wood-concrete composite floor/deck systems with shear key connection detail. Journal of Structural Engineering, 133(9), 1307-1315.

Fragiacomo, M., \& Schänzlin, J. (2013). Proposal to account for environmental effects in design of timber-concrete composite beams. Journal of Structural Engineering, 139(1), 162-167.

Grantham, R., Enjily, V., Fragiacomo, M., Nogarol, C., Zidaric, I., \& Amadio, C. (2004). Potential upgrade of timber frame buildings in the UK using timber-concrete composites. In Proceedings 8th World Conference on Timber Engineering. Lahti, Finland.

Gutkowski, R. M., Balogh, J., Natterer, J., Brown, K., Koike, E., \& Etournaud, P. (2000). Laboratory tests of composite wood-concrete beam and floor specimens. In Proceedings of World Conference on Timber Engineering 2000. Whisthler Resort, BC, Canada.

Gutkowski, R. M., Balogh, J., Rogers, C. C., \& SaRibeiro, R. A. (2002). Laboratory tests of deep composite wood-concrete beam and deck specimens. In Proceedings of the 4th Structural Specialty Conference of the Canadian Society of Civil Engineering (pp. 1-9). Quebec, Canada: 30th Annual CSCE Conference Montreal.

Gutkowski, R. M., Balogh, J., SaRibeiro, R. A. (2001). Modeling and testing of composite wood-concrete deep beam specimens. In Proceedings of STRUCTURAL FAULTS + REPAIR-01, 10th International Conference and Exhibition. London, UK.

Gutkowski, R. M., Brown, K., Shigidi, A., \& Natterer, J. (2004). Investigation of notched composite wood-concrete connections. Construction and Building Materials, 22, 1059-1066.

Gutkowski, R. M., Brown, K., Shigidi, A., \& Natterer, J. (2008). Laboratory tests of composite wood-concrete beams. Journal of Structural Engineering, 130(10), 1553-1561.

Gutkowski, R. M., \& Chen, T.-M. (1996). Tests and analysis of mixed concrete-wood beams, In Proceedings of the International Wood Engineering Conference (pp. 3.436-3.442). Madison, WI: Omnipress.

Gutkowski, R. M., Thompson, W., Brown, K., Etournaud, P., Shigidi, A., \& Natterer, J. (1999a). Laboratory tests of composite wood-concrete beam and deck specimens. In
Proceedings of 1999 RILEM Symposium on Timber Engineering (pp. 263-272). Stockholm, Sweden.

Gutkowski, R. M., Koike, W. E., Etournaud, P. J.-F., \& Natterer, J. (1999b). Laboratory tests of composite wood-concrete beam and deck specimens. In Proceedings of STRUCTURAL FAULTS + REPAIR-99, 8th International Conference and Exhibition. London, UK.

Lukaszewska, E., Johnsson, H., \& Fragiacomo, M. (2008). Performance of connections for prefabricated timber-concrete composite floors. Materials and Structures, 41(9), 1533-1550.

Natterer, J. (1997). Sustainable economy of forestry and value added utilization of forests: The only chance to save the forests of the world, State-of-the-Art Paper in Restoration of Forests-Environmental Challenges in Central and Eastern Europe. In R. Gutkowski, \& Winnicki, T Proceedings of the NATO Advanced Research Workshop on Science and Technology to Save and Better Utilize Central and Eastern Europe's Forests (pp. 97-118). New York, NY: Kluwer Academic Publishers.

Pault, J. D., \& Gutkowski, R. M. (1977). Composite action in glulam timber bridge systems, Structural Research Report No. 17B, Civil Engineering Department, Colorado State University, Ft. Collins, CO.

SáRibeiro, R. A., Rocha, J. S., \& SáRibeiro, M. G. (2006). Vigas de madeira-concreto com conectores de resíduos de construção. In Anais/BRASIL NOCMAT 2006-SalvadorConferência Brasileira de Materiais e Tecnologias NãoConvencionais: Materiais e Tecnologias para Construções Sustentáveis (pp. 1-7) (in Portuguese).

SáRibeiro, R. A., \& SáRibeiro, M. G. (1990). Mechanical properties of Amazonian lumber for the development of design stresses. In Proceedings of the 1990 International Timber Engineering Conference (Vol. 3, pp. 819-826). Tokyo, Japan.

Wegener, W., \& Zimmer, B. (1998). The ecological benefits of increased timber utilization, In Proceedings of the 5th World Conference on Timber Engineering (Vol. 1, pp. 1656-1663). Montreux, LA: Presse polytechniques et universitaires romandes.

Winter, W. (1998). Economical and ecological aspects of multistory timber buildings in Europe. In Proceedings of the 5th World Conference on Timber Engineering (Vol. 1, pp. 1664-1668). Montreux, LA: Presse polytechniques et universitaires romandes. 